\title{
INFORMAL HOUSING IN GLOBAL CITIES: CASE STUDIES ON HONG KONG, NEW YORK CITY, AND TORONTO
}

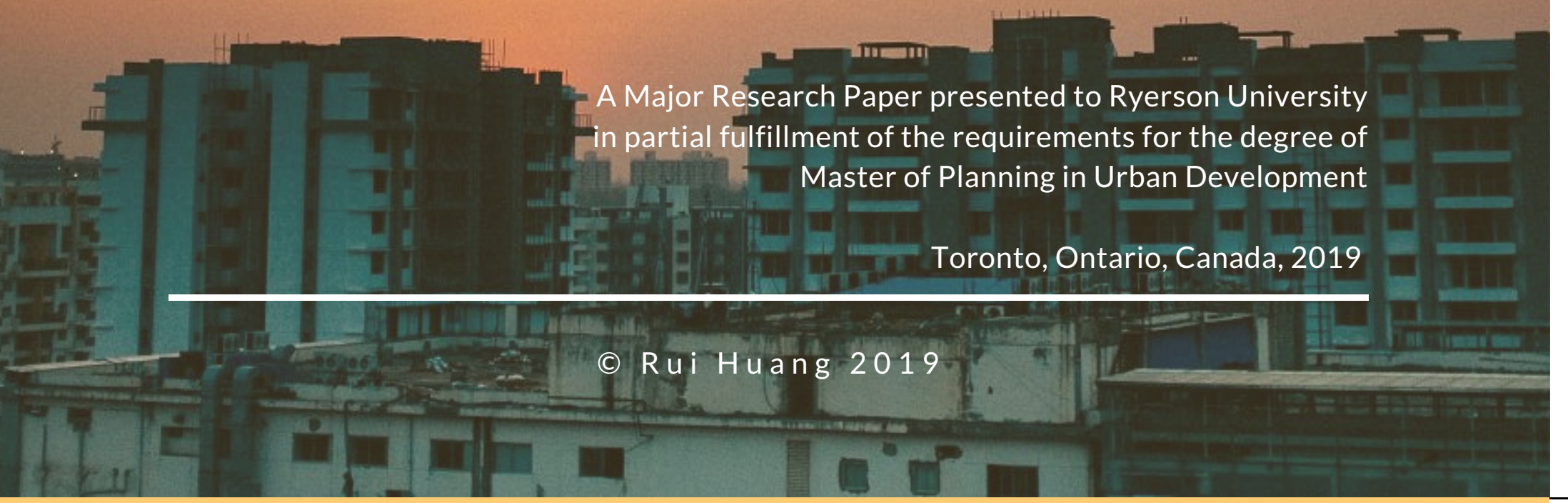




\section{AUTHOR'S DECLARATION}

I hereby declare that I am the sole author of this MRP. This is a true copy of the MRP, including any required final revisions.

I authorize Ryerson University to lend this MRP to other institutions or individuals for the purpose of scholarly research.

I further authorize Ryerson University to reproduce this MRP by photocopying or by other means, in total or in part, at the request of other institutions or individuals for the purpose of scholarly research.

I understand that my MRP may be made electronically available to the public. 
C Rui Huang 2019
Master of Planning

in

Urban Development

Ryerson University

\begin{abstract}
This paper examines the major characteristics and drivers of informal housing in three global cities. Despite each city's unique path to urbanization, Hong Kong, New York City, and Toronto are experiencing housing issues that are reflective of many developed, wealthy cities around the world. Continued population increase from globalization, rising property costs, and insufficient housing stock has contributed to the persistence of various forms of housing that exist outside of formal processes. The case studies exposed distinctive socio-economic and political drivers that underlies this international phenomenon. The findings revealed a continuum of informal dwelling typologies that span across a spectrum of legality and illegality, ranging from highly visible structures to those that are more hidden. This research responds to the need to understand shared challenges between cities in the East and in the West, and may be particularly relevant to city builders who are concerned about distributive justice.
\end{abstract}

Key words: informal housing, informal settlements, global cities, public housing, urban development 


\section{ACKNOWLEDGEMENTS}

Thank you to my supervisor, Dr. Zhixi C. Zhuang. It was because of a conversation we shared that inspired me to pursue this research topic. Your guidance, knowledge, and support throughout this entire writing process and over the past two years has been invaluable.

Thank you to my second reader, Cassandra Alves, for taking time to review my MRP while being on vacation. Cassandra, I deeply appreciate your time and thoughtful feedback.

To my colleagues and professors at Ryerson University's School of Urban and Regional Planning, you have all inspired and motivated me with your brilliant minds and big hearts. Thank you for an incredibly fun and rewarding two years, I will always cherish our time together.

To my parents, I will never be able to thank you enough for all the sacrifices you've made for me - thank you for being there through it all. To my sister, pa(w)tner, and friends, thank you for being my balance and the absolute best support system. 


\section{TABLE OF CONTENTS}

$\begin{array}{ll}\text { Introduction } & 1\end{array}$

Literature Review

Research Methods $\quad 6$

$\begin{array}{ll}\text { Informal Housing in Hong Kong } & 7\end{array}$

Informal Housing in New York City 14

$\begin{array}{ll}\text { Informal Housing in Toronto } & 21\end{array}$

Discussion $\quad 29$

$\begin{array}{ll}\text { Conclusion } & 35\end{array}$

Reference List $\quad 36$ 


\section{INTRODUCTION}

Population growth in 21st century cities are driven by both international and rural-to-urban migration (Massey, 2003). Due to this trend, many cities are becoming denser and more diverse. Growing cities such as Hong Kong, New York City, and Toronto need to ensure a wide range of housing options to serve its diverse population. When appropriate housing provisions are not properly delivered, and market supply fails to meet demands, city dwellers are often forced to look beyond formal housing options to secure their own basic needs. As a result of urban development, cities in the Global North and the Global South are seeing similar markers of urban change - one of which being informal housing.

In the last twenty years, there has been a paradigm shift in the literature surrounding informal housing. One from associating them solely with poverty within cities, to a discourse that recognizes this phenomenon as a process of metropolitan urbanization (Wang et al., 2009). Researchers have also rejected the idea that there is a clear line between formal and informal housing, rather what exists is a complex continuum of legality and illegality (Lai, 2015). This paper seeks to build on this paradigm shift to explore three Global Cities that all fall on a different point of this complex continuum. This paper will answer the following questions:

- What are the major characteristics of informal housing?

- In what context do they exist and what are the specific socio-economic and political circumstances in each city?

- What is the reasoning behind the persistence of informal housing?

- How have they been addressed through policy and planning interventions? 
The findings of this major research paper responds to the need to better understand the state of informal housing in contemporary global cities, emerging trends, and offer insights from a transnational, comparative perspective. This paper argues that wealthy cities such as Hong Kong, New York City, and Toronto should not be excluded from the global discussion of informal housing. Moreover, cities in the Global North can learn from the adaptability, sense of community, and resilience of informal housing arrangements in the Global South. 


\section{LITERATURE REVIEW}

\section{Informal Urbanism}

Scholarly discussions of informal settlements exist within a larger context of informal urbanism. UN Habitat defines informal urbanism as "the production of urbanization independent from formal frameworks and assistance (if they exist) that do not comply with official rules and regulations" (UN Habitat, 2012). In most cases, informal urbanism is driven by the absence, insufficiency or unaffordability of dwelling options for some social groups (UN Habitat, 2012). While this is one of the many definitions to describe informality within cities, the term is also used to describe a wider range of informal processes that exists in an urban context. Mukhija and LoukaitouSideris (2014) identified various settings in which informal urbanism exists in American cities, these include but are not limited to the informal economy, the reproduction of informality in low-income self-help housing communities, claims and informal property rights on sidewalks, illegal street vendors, and informal parking markets. Much of the world's urbanization now occurs in the informal sector, outside of institutional structures such as building regulations, zoning by-laws, or land tenure. Moreover, the extent and expression of informal urbanism varies significantly between cities and even communities - the three 'Global City' case studies explored in this paper are no exception to this phenomenon.

\section{Emergence of Informal Settlements}

Research on informal settlements primarily emerged with a focus on the Global South. Various scholars in recent years have contended that informal dwelling units (albeit typically less visible), also exists within cities in the West (Durst \& Wegmann, 2017; Mukhija \& Loukaitou-Sideris, 2014). Durst \& Wegmann (2017) observed that informal housing in US housing markets is sustained by three characteristics: noncompliant, non-enforced, or deregulated economic activity. Their research concluded that informal housing in the US is geographically uneven, largely hidden and typically 
interwoven within formal markets. For this reason, when the concept of informal housing is used in the US context, it is often met with skepticism.

Al (2014) also noted that developed nations prefer to use the term "extra legal" or "unplanned communities" to describe informal dwelling types within cities. Comparing this to cities in the Global South, informal housing tend to be highly visible as such exhibited by the favelas in Rio de Janeiro, barrios in Mexico, or shantytowns in India. It is therefore necessary to categorize a wide variety of informal housing to contribute to the global housing conversation. The emergence of informal dwellings in Hong Kong, New York City, and Toronto fits an international trend of emerging informal settlements.

\section{Implications for Planning}

In Roy's (2005) critique of planning theory towards informal housing, she shed light on how the apparatus of planning may produce both the unplanned, and the unplannable. These "exceptions" to the order of formal urbanization should be a matter of concern to planners as the implications are beyond the physical realm, and extends to social, cultural, economic, environment, governance, and policy issues. After three decades of debate, there is a broad consensus amongst city builders that upgrading the settlements in situ is the most appropriate way to include informal settlements in the urbanization process. Abbott (2002) noted that simply using quantifiable measures (e.g. improving water connections) is not enough to assess the success of physical upgrades as they fail to account for much broader impacts of vulnerability and social exclusion within cities. Abbott (2002) suggested that the lack of traditional planning and engineering responses to informal settlement upgrading means a new method-based approach is required. Such a method-based approach, Abbott explains would entail settlements that become self-sustaining, with internal cohesion and the ability to mesh with the wider urban fabric. Achieving this would require a move away from a development perspective, to an approach that views informal settlements as part of the broader urban renewal process. 
One of the major challenges of any form of informal settlement dwelling upgrades has to do with the temporary or permanent relocation of residents. In many developing regions that are undergoing rapid urbanization, such as Shenzhen (China), informal settlements are viewed as a "problem" to be dealt with, and local governments are eager to regain control of prime real estate land (AI, 2014). Historically, there has also been examples where thousands of informal settlement dwellers have had to relocate overnight due to natural disasters or other reasons, such as the Shek Kip Mei fire in 1953. Such examples raise concerns of the overall safety and building conditions of informal settlements, but also points to the vulnerability and the lack of social security of the already underprivileged. Al (2014) argues for the value of informal settlements as places. Though much academic research has focused on their role in providing affordable housing to a migrant population, it has been noted that they have insufficiently been approached from a planning and urban design perspective. It is in fact the urban design perspective that could persuade governments to integrate informal housing dwellers into, rather than expel them from cities.

There are also lessons to be learned from informal settlements. Researchers have noted of their intimate and human-scaled urban fabric, smaller blocks, and pedestrianized connections. Others have documented the general trend of polarization in world cities and the need to counteract these trends through planning (Chen et al., 2018). 


\section{RESEARCH METHODS}

This research paper employs both qualitative and quantitative research methods to unveil contemporary typologies of informal housing in Hong Kong, New York City, and Toronto. The background review primarily draws on existing theoretical discussions of informal settlements and English-based scholarly research articles; news articles from major publishers were also used to supplement findings. The three cities examined in this paper were in-part chosen because of the availability of open source data. Government-published census data from all three cities were reviewed and a demographic analysis was conducted for each city based on population trends and various socio-economic factors such as average dwelling unit price, employment rates, household size, and immigration levels.

To understand the municipal planning context and existing policies of each city, publically available municipal reports and relevant grey literature was surveyed. The findings of this research revealed a continuum of informal dwelling typologies that span across a spectrum of legality and illegality, ranging from highly visible structures to those that are more hidden. Through employing these methods, this research has identified key typologies in each of the respective cities and reasons for their persistence. While the current socio-economic and political context of the cities were examined, this paper does not provide a historical overview on the development of the three cities. Rather, this research focuses on the contemporary manifestations of informal housing from a comparative, international perspective. Future research could build on the findings of this research paper by providing up-to-date policy comparisons and expanding looking at more cities around the world. 
Hong Kong is formally considered a Separated Administrative Region (SAR) in the People's Republic of China (PRC). It is also one of the fastest growing megacities in the world - particularly gaining traction in the late 20th century. Despite Hong Kong's rapid rise to global city status, the existence of informal settlements have persisted throughout its urbanization journey. To begin the look at informal settlements in Hong Kong, this chapter will provide a brief overview of the planning context in the region, and explore the unique socio-economic and political forces that created and continues to sustain the existence of informal settlements in Hong Kong SAR. The impacts of current policies on informal settlements will then be examined through a case study on Tung Ah Pui Village, and conclude with a discussion on the current challenges for the region. The terms squatter settlements and squatter structures have been widely used to describe the main informal settlement typology in Hong Kong SAR. While this chapter will shed light on the various types of housing informality in the region, a significant portion will be dedicated to providing a deeper analysis on squatter settlements.

According to the Government of Hong Kong's Census and Statistics Department, Hong Kong had a population of 7.4 million inhabitants as of 2018 . The population has increased at an average annual growth rate of 0.9 percent in the past 3 decades. The average household size is 2.8 persons and homeowners makes up 49 percent of the population (Government of Hong Kong Census and Statistics Department, 2019). In recent years, Hong Kong is experiencing a tightening of labour market despite overall expansion of the Hong Kong economy, with grassroots workers enjoying the most visible growth in earnings. Yet this growth is offset by the ongoing trend of population aging, and a growing number of households reaching the poverty line (Government of Hong Kong, 2017). The median age of the population rose from 28 in 1986 to 43 in 2016, this trend is attributed to declining fertility and increases in life expectancy levels. 
The Government of Hong Kong defines the purpose of town planning as:

"Shaping a quality living and working environment, facilitating economic development, and promoting the health, safety, convenience and general welfare of the community by guiding and controlling development and the use of land. Based on the principle of sustainable development, town planning seeks to bring about an organized, efficient and desirable place for the community to live and work in." (Government of Hong Kong, 2018)

Based on its mandate, the government plays a central role in deciding what should be built and where. The principle planning organizations within the government are:

- The Development Bureau Planning and Lands Branch (the highest authoritative body in charge of the policy portfolios of planning, land use, buildings an urban renewal);

- The Planning Department or PlanD (takes directives from the Development Bureau and is responsible for formulating, monitoring and reviewing land use the territorial and district/local level); and

- The Town Planning Board or TPB (the principal body responsible for statutory planning in Hong Kong), under which two standing committees have been created - the Metro Planning Committee and the Rural and New Town Planning Committee

Hong Kong's planning structure follows a hierarchical order, with development strategies presented at the territorial level, and various statutory and departmental plans at the district/local level. The Hong Kong Planning Standards and Guidelines and the Hong Kong 2030: Planning Vision and Strategy are two high-level planning policies that govern much of the planning process and long-term strategies for the region, yet neither mention of a desired outcome for those residing in vulnerable living tenements or squatter settlements. In Chapter 4 of the Hong Kong 2030 report, the policy vaguely mentions the need to provide fair access to urban infrastructure. 


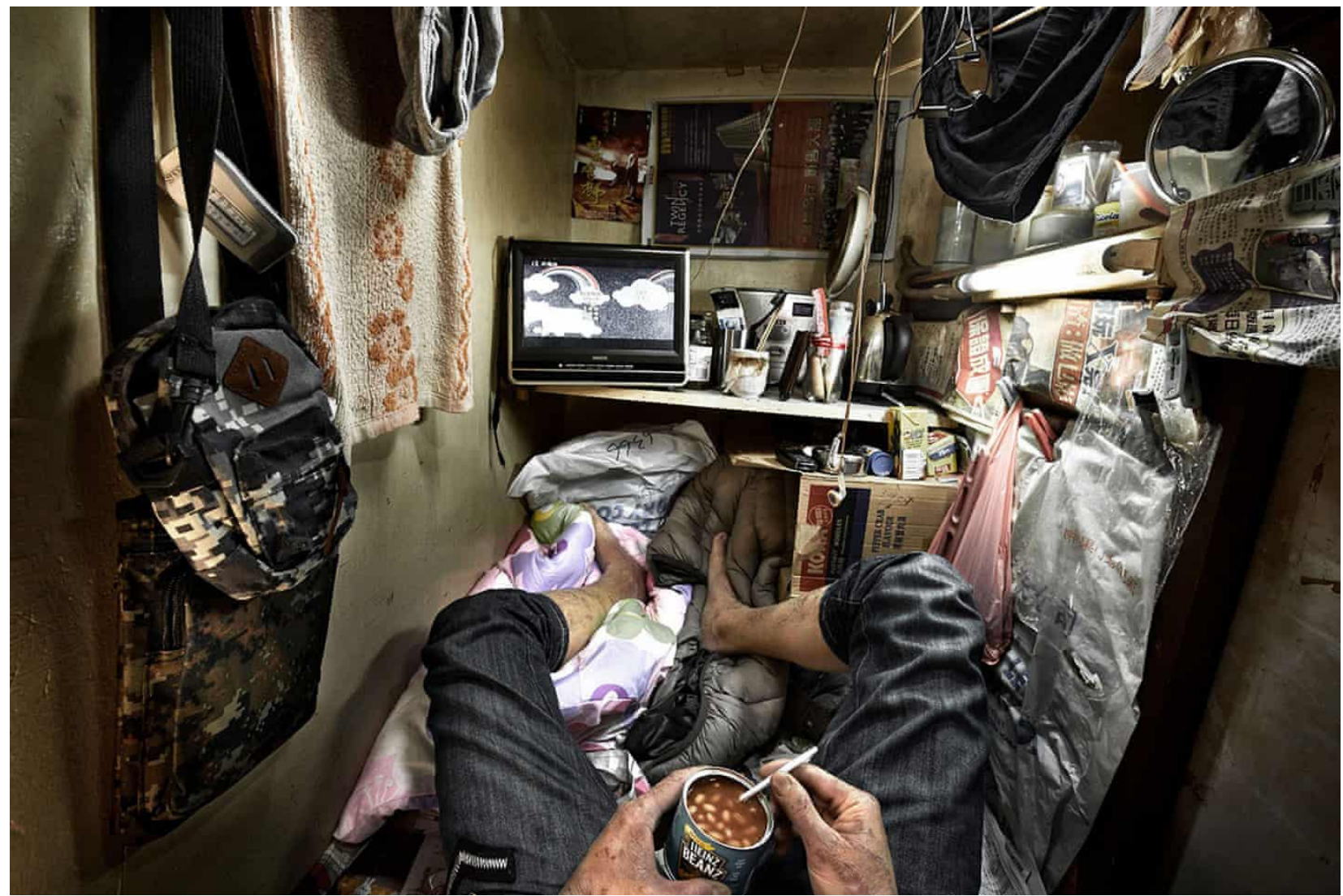

Image 1. Inside of a cage home in Hong Kong (Lam, 2017).

In terms of morphology, the prominent expressions of informal settlements include cage houses, shanty/squatter structures (i.e. street structures and extended structures), urban inbuilt building informal settlements (rooftops), and scattered temporary including affordable housing, public transport, health services, and education (Government of Hong Kong, 2007).

The variations of housing informalities in Hong Kong can be described both in terms of typology and morphology. The types of housing informalities in Hong Kong fall within five categories:

- Illegal land/building ownership;

- Haphazard building;

- Unauthorized settlement;

- Unplanned zoned uses; and

- Inadequate facilities and services settlements 
ettlements. The physical characteristics of informal housing tenements vary based on location, needs, and duration of usage.

\section{Public Housing Provisions}

During the period between 1945-1949, Hong Kong's population experienced a rapid decline followed by a significant increase as a result of political escalations in mainland China. In 1948, there were 20, 000 squatters on Hong Kong Island and 10, 000 in Kowloon; by 1949, the number of squatters jumped to 300,000 . Squatting in Hong Kong largely emerged as a response to the lack of housing amongst refugees from mainland China, where they occupied war-damaged buildings on crown or private lands. Although the explanations for the commencement of housing basedstate provisions in Hong Kong varies throughout the literature, Hong Kong's housing programme would eventually provide dwellings for more than half of its population. Hong Kong's public housing policies can be traced back to 1953, following what is now widely known as the Shek Kip Mei fire that destroyed thousands of squatter housing units, known as shanty homes. This event prompted the Hong Kong administrative government to initiate a formal Resettlement Programme in the following year with the goal to overlook the region's public housing developments. The Hong Kong government's provisions to public housing program has been studied extensively by Dr. Alan Smart (University of Calgary, previously University of Hong Kong). Smart traces the convergence of the state's regulations and squatters to the beginning of the Resettlement Programme, which he argues immediately resulted in tensions between squatter dwellers and the administrative government (Smart, 1989).

\section{Social, Economic, and Political Forces}

The socio-economic factors that produce squatter settlements in Hong Kong include: intensified urban functions, a dynamic and rapidly growing economy, lack of developable land, challenges of keeping urban open space, high cost-of-living, 
inadequate infrastructure, and deteriorating living conditions and environments (Soyinka \& Siu, 2017). Social inequality, limitations on accessing resources (i.e. health care, education), and the irregular development policy in Hong Kong further contributes to the persistence of informal housing (Soyinka \& Siu, 2017). The combined effect of these circumstances makes it extremely difficult for those in the lower social classes to improve their quality-of-life.

In the mid-1960s, roughly 35 percent of all structures in squatter settlements served an economic function. Industries that emerged include shoemaking, metalworks and plastic manufacturing, and gradually diversified to include film studios, distilleries and furniture makers (DeWolf, 2017). These informal industries played a key role in fostering the economic development of Hong Kong due to the large portion of the population that lived in squatter settlements.

In a 2003 article, Smart discusses why self-help has never been allowed in the improvement of squatter dwellings, and how the Hong Kong government actively controls and regulates these areas in order to prevent improvements. Even though squatter upgrading has been argued to be more effective than demolition and rehousing policies, the Government of Hong Kong has never adopted policies to legalize informal housing. Smart hypothesizes that the Hong Kong government's prohibition on housing upgrading is primarily related to the broader management of the housing conditions of the Hong Kong population; delaying the complete eradication of the urban squatter areas, and the prospect of long-term persistence without tenure regularization avoids an increase of the short-term rehousing commitment that might upset the careful balance of the property market, the administration's revenues and budget management (Smart, 2003). 


\section{Case Study: Tung Ah Pui Village}

Tung Ah Pui Village is located on the southeast portion of Hong Kong Island. In a 2016 press release, the Lands Department announced its investigations into the informal settlement, along with the government's anticipated follow-up actions. The Lands Department identified 12 squatter dwellings in Tung Ah Pui Village that are currently located on government-owned land.

Hong Kong Lands Department identifies and enforces unauthorized squatter structures through Squatter Control surveys. Based on the Squatter Control Survey (1982), all squatter structures situated on government-owned land and leased agricultural land must have a squatter survey number on the dwelling unit. The Squatter Control Survey (1982) also recorded the location, dimensions (i.e. length, width, height), building materials and use of the Surveyed Squatter Structure. The policy explicitly states that the "[g]overnment's position is that any Surveyed Squatter Structure on Government land and any Surveyed Squatter Structure on leased agricultural land is an unauthorised structure on leased agricultural land, but they are tolerated to remain on a temporary basis, provided the location, dimensions, building materials and use are the same as the record in the 1982." (Hong Kong Department of Lands, 2016) Squatter structures that do not deviate from their historical records (including those in respect to materials, dimensions, and uses of the structures) are allowed to persist as per the Lands Department's current policy provisions. Thus, the current squatter control regulations are based on the SCS records from 1982. Of the 12 squatter dwellings surveyed, it was found through aerial photography that the dimensions of three squatter structures are inconsistent with the 1982 SCS records. To address such inconsistencies, the Lands Department will issue warnings asking the occupants to resolve the irregularities within 28 days, or they will find their SCS records annulled and their squatter structures demolished in whole. 
It is evident that the practice of repression and exclusion have persisted in the Hong Kong government's treatment of informal settlements, in a sense freezing any form of social or economic advances from 1982 regulations. These enduring regulations manifest in the form of physical, socio-economic, and psychological hindrances. According to the Squatter Control Policy (2016), the only form of altercations permitted fall within the realm of rebuilding and repairs, however approval must be obtained from the Squatter Control Office of the Lands Development first. All aspects of the structure, including location, dimensions, buildings materials used to rebuilt squatter structures must remain the same as the SC Survey Record. The squatter control regulations perpetuate existing inequalities and social divides by restricting any physical upgrades to the living units. This also has psychological implications on the residents, as they are prevented from improving their quality-of-life even if they possess the means and resources to do so.

\section{Current Challenges}

The government of Hong Kong's Lands Department exerts control over all government-owned lands through district-based Squatter Control Offices (SCOs) and District Lands Offices (DLOs) to exercise state enforcement. Squatter Control Officers actively survey squatter settlements, and even in remote places like the Tung Ah Pui Village, the Squatter Control units conduct inspections once every three months. The existing regulations suggest that the future of this squatter settlement remains highly unpredictable, and its persistence relying completely at the mercy of the government.

Based on a 2017 qualitative study looking at public perceptions of residents, researchers, professionals, and stakeholders on the types of informal settlements that are present in Hong Kong, inadequate facilities/services and haphazard building were of more concern than the existence of informal settlements in unplanned zones and those under illegal land/building ownership (Soyinka \& Siu, 2017). 
According to this study, issues surrounding infrastructure and the visible attributes of informal settlements held more weight to the public than bureaucratic formalities. At the same time, public housing in Hong Kong is considered inadequate when compared to its international counterparts. Lai (2015) compared the cost of social housing rentals in Hong Kong and the UK. The research concluded that the cost of social housing rentals in Hong Kong is significantly higher, yet there is a lower provision of basic services and overall quality of life (Lai, 2015). A part of this can be attributed to pressures Hong Kong is facing in terms of a lack of resources and developable land, while researchers have also noted irregular land policies regarding informal settlements (Lai, 2015). 
The rise of New York City as a global node is rooted in its long history as a trading port, connecting it to the rest of the world, while also playing an important role in the settlement patterns of various immigrant populations and migration periods. Today, it is both the most dense and populous city in the United States (The New York Times, 2018). The City famously consists of five boroughs - Brooklyn, Queens, Manhattan, The Bronx, and Staten Island - which were consolidated in 1898 as the City of New York. With almost 9 million inhabitants and its reputation on the global stage, it is hardly surprising that the real estate market is a significant contributor to the City's economy (New York City Department of Finance, 2016).

\section{Demographics}

The last population census in New York City was conducted in 2012. The United States Census Bureau estimated in 2017 that the City's population was sitting around 8.6 million (The New York Times, 2018). Every three years, the City conducts a Housing and Vacancy Survey (HVS). From 2014 to the most recent HVS conducted in 2017, New York City experienced the largest increase in its housing stock since the 1965 with a total of 69,000 units added (City of New York, 2018). There are currently more than 3.5 millions households living in the metropolitan area. Rental units comprised 63 percent of the City's housing stock in 2017, and only 30 percent represented owner units (City of New York, 2018). Between the five boroughs, the

rental vacancy rate was highest in Manhattan at 4.73 percent, the lowest in the Bronx at 2.7 percent. In New York City, vacancy rates below 5 percent represent a severe shortage of housing stock. Evidently, the City is experiences housing shortages in all five neighbourhoods. 
The Department of City Planning (DCP) is New York City's principal planning body, and is responsible for setting the City's physical and socioeconomic frameworks (Department of City Planning New York, 2019). The DCP is governed by five Strategic Objectives, of which Housing is considered one of the central priorities to encourage. The DCP provides technical support to the NYC City Planning Commission, which was established in 1936 and is responsible for:

“...[T]he conduct of planning relating to the orderly growth and development of the City, including adequate and appropriate resources for the housing, business, industry, transportation, distribution, recreation, culture, comfort, convenience, health and welfare of its population." (Department of City Planning New York City, 2019)

The Commission meets regularly to vote on applications regarding the use, development and improvement of properties subject to city regulation.

New York was the first city in the US to adopt zoning regulations (formally known as the Zoning Resolution) in 1916 as a result of complaints regarding the impacts of taller buildings, such loss of light and air quality (Department of City Planning New York City, 2019). The Zoning Resolution was also in part influenced by the influx of immigrants, driving a shortage in the formal and informal housing market, and eventually led zoning restrictions for separating various land uses. 5 It has been widely regarded as an influential act and has since inspired cities around the world to adopt similar policies. The zoning laws and building code are the main regulatory tools that govern the use, development, and improvement of properties. In the event of a suspected Building Code violation, the Department of Buildings is responsible for investigating properties and when required, however enforcement of punishment is passed to the Environmental Control Board where fines are the City's main punitive tool. Owners may also pursuit zoning variance approvals by going before the Board of Standards and Appeals to request exemption. 


\section{Physical Characteristics}

New York City's informal ("underground") housing encompasses a wide range of typologies and is overall geographically uneven, largely hidden, and typically interwoven within formal markets (Durst \& Wegmann, 2017). One of the earliest manifestations of informal housing in New York City is the tenement housing era in the early 20th century. Morphologically, they were the largest, tallest, and bulkiest buildings that could be crammed into a single parcel of land with little considerations for the livability of the units (Waldrep, 2009). Tenement housing were developed all through Manhattan's downtown core, and resembled squatter settlements.

Although evidence of informal tenements exist in all five boroughs, Queens accounted for more than half of the 90,000 informal housing complaints filed between 1992 and 2002. Much of the underground housing in New York City takes the form of informal densities, where alterations to an existing property for the purpose of creating additional residential units. However, this must be approved by the Department of Buildings (DOB), otherwise the structures are considered illegal. Some owners also fail to pursue the required documentation, thus essentially existing under the radar of the DOB (Citizens Housing and Planning Council, 2003).

Rooming houses and unintended uses of commercial or manufacturing spaces such as converted garages may also be illegal, while other forms of informal settlements may in fact comply with the Building Code and zoning regulations, but simply lack appropriate documentation. Scholars also argue that homelessness should be considered as a form of informal housing and would fall into the category of living in defiance of property ownership (Roy \& AISayyad, 2004; Durst \& Wegmann, 2017). This ties into the grey area of individual outdoor sleeping on public-owned land, including but not limited to vehicle living, and homeless settlements under municipal road infrastructures such as expressways and bridges. 


\section{Public Housing Provisions}

One of the biggest public housing projects in New York City's recent history is the Mitchell-Lama Program, created in 1955 to provide affordable rental and cooperative housing to moderate and low-income families. The Program was sponsored by New York Senator MacNeil Mitchell and Assemblyman Alfred Lama. Under the Program, a total of 269 state-supervised developments were built, creating 105, 000 affordable housing units (New York State Homes and Community Renewal, 2019). In 2003, the Citizens Housing and Planning Council estimated that informal housing in New York City may constitute a similar figure to that of the Mitchell-Lama Program (Citizens Housing and Planning Council, 2003).

The Housing Choice Voucher (HCV) Program is a federally-funded program that provides financial assistance to help low-income families nationwide afford decent, safe, and sanitary housing in the private rental market (Unites States Federal Government, 2019). Voucher holders are personally responsible for finding a suitable dwelling and may rent from privately-owned apartments, single-family homes, or units within subsidized housing projects. A program evaluation showed an increased standard of living for the families supported by this program, including improved neighbourhood quality, better unit quality, and enhanced economic opportunities; however, the program has also been criticized for its administrative complexity, eligibility conditions, and expensive operational costs (Kutty, 2005). 


\section{Social, Economic, Political Forces}

Due to the immense demand for affordable housing in New York City, as well as the volume of informal tenements that have been flagged and are awaiting inspection, the City simply does not have the time and financial capacity to enforce all housing arrangements and zoning. The social construction of formal housing that gives rise to informal housing also varies substantially between jurisdictions and states, resulting in unequal reporting and enforcement.

Durst and Wegmann (2017) examined five interrelated regulatory regimes based on three forms of informality - non-compliant, non-enforced, and deregulated economic activity. The conceptual framework summarized below sheds light on various laws and regulatory processes that contribute and sustain housing informality in the US.

\begin{tabular}{|l|c|c|c|}
\hline & Non-compliant & Non-enforced & $\begin{array}{c}\text { Deregulated } \\
\text { Economic Activity }\end{array}$ \\
\hline $\begin{array}{l}\text { Property Rights } \\
\text { Protection }\end{array}$ & $\checkmark$ & & \\
\hline $\begin{array}{l}\text { Property Transfer } \\
\text { Laws }\end{array}$ & & & $\checkmark$ \\
\hline $\begin{array}{l}\text { Land-use and } \\
\text { Zoning laws }\end{array}$ & & & $\checkmark$ \\
\hline $\begin{array}{l}\text { Subdivision } \\
\text { Regulations }\end{array}$ & & & $\checkmark$ \\
\hline Building Codes & $\checkmark$ & $\checkmark$ & \\
\hline
\end{tabular}


Examples of non-compliant property rights include homeless settlements on publicly-owned land, urban campers, and in some cases where residents assume stewardship of abandoned buildings, or any form of trespassing.

Property transfers as deregulated economic activity refers to any informal pathways to homeownership, including in the absence of a will, and informal sales of property that are not enforced or monitored by real-estate agents, lawyers, insurance companies, and independent inspectors.

Land-use and zoning regulations are widespread, however changes made to properties may be "hidden from view", since informal living spaces tend to exist within properties whose ownership is fully legal. Land-use transgression can also be linked to local policies and visibility, where the governmental legitimization of certain activities in some areas but not in others gives rise to informality as deregulation.

Subdivision regulations fall under deregulated economic activity, with examples of developers selling undeveloped or 'premature subdivisions', and finally, the building code regime is linked to both non-compliant and non-enforced forms of informality, new construction on the one hand, and the maintenance and repair on the other.

\section{Current Challenges}

Some of the current challenges surrounding the persistence of informal housing in New York City is driven by the DOB's enforcement policy, which is complaintdriven due to both the backlog and incapacity to actively seek out illegal units. Legal and bureaucratic obstacles also hinder investigations, and several of the State's enforcement agencies are not legally permitted to enter apartments without a court order or a cooperative tenant or landlord. When investigations do reveal illegal units, unless they are in dangerous of uninhabitable conditions, landlords are given a grace period to correct violations. The DOB can issue a vacate order if a dwelling is deemed immediately dangerous, but rarely does so because of the shortage of relocation options. There is also little to deter homeowners from creating new illegal dwellings and 
is difficult for the state to ensure that existing units are permanently removed from the market. 


\section{INFORMAL HOUSING IN TORONTO}

Historically, the three largest urban centres - Toronto, Montreal, and Vancouver - have absorbed nearly all newcomers to Canada (Chui et al., 2018). For the most part, Toronto's immigration trends have not strayed far from its longstanding history. As a key economic engine of Canada, Toronto attracts not only newcomers, but skilled professionals, international students, and global corporations. Creating and maintaining affordable housing for current and projected population demands is one of the City of Toronto's strategic priorities.

Affordable housing is a key factor in ensuring the City's economic success. However, more than 640, 000 thousand people in Toronto are in need of some form of housing assistance (City of Toronto, 2009). Given that the population of Toronto was 2.7 million in 2016, this is a colossal statistic and students, seniors, people with disabilities, Aboriginals, low-income workers, and new Canadians are amongst some of the most vulnerable subpopulations. Adding to this, the City estimate that 200, 000 tenant households currently live in housing that is considered unaffordable (City of Toronto, 2009).

\section{Demographics}

Toronto's population saw a 4.5 percent net increase (or 116, 511 residents) between 2011 and 2016. Toronto's highest growth neighbourhoods are located in the downtown area. According to the Canada Mortgage and Housing Corporation $(\mathrm{CMHC}), 84,748$ dwelling units were added to the housing stock between 2011 and 2016, and it was reported that 96.2 percent of the units were absorbed, meaning there is a strong demand for housing in the City (City of Toronto, 2017a). As a traditional measure of housing affordability, Statistics Canada and CMHC use the percentage of income households spend on shelter as a measure of affordability. If a household spends more 
than 30 percent of their before-tax income on shelter, they are considered to be experiencing affordability issues. By this measure, 37 percent of Toronto's 1.1 million households spent more than 30 percent of their before-tax income on shelter in 2016 (City of Toronto, 2017b). Toronto continues to have a higher rate of low income than the rest of Canada (averaging around 14.2 percent). Areas with the lowest rates of low income can be found in the following areas of the city: south west Etobicoke, central Toronto, and north east Scarborough.

\section{Planning Context}

The City of Toronto is a single-tier city that assumes all municipal responsibilities as outlined in the Municipal Act and various Provincial legislations. The housing system consists of multiple divisions and City-owned agencies that work towards delivering rental and ownership housing solutions to residents in need, including the Affordable Housing Office and the Housing and Shelter Division. The City regulates built forms through various official planning documents, zoning by-laws and urban design guidelines. The RentSafeTO: Apartment Building Standards is a bylaw enforcement program that applies to all buildings that are three or more storeys, or ten or more units. Toronto's housing system is guided by several strategic policies such as Housing Opportunities Toronto: Affordable Housing Action Plan 2010-2020, Toronto Seniors Strategy Version 2.0, the Toronto Poverty Reduction Strategy and Housing Stability Service Plan (City of Toronto, 2019a). A new Toronto Housing Strategy looking forward to 2020-2030 will be implemented in 2019 and the City will also see the full roll-out Canada's first National Housing Strategy, which will include co-funding from both the federal and provincial governments.

\section{Physical Characteristic}

Informal housing in Toronto shares similar characteristics as what is observed in US counterparts; namely, the distribution of informal housing arrangements is 
geographically uneven and largely hidden. One of the most prominent recent examples of informal housing in the Toronto context is the emergence of rooming houses. The City of Toronto defines one as "a house, apartment or building where you share a kitchen and/or washroom with four or more people who each pay individual rent". (City of Toronto, 2018) Historically, rooming houses were regarded as a last resort to housing; they were and some still are poorly maintained, crammed, and do not comply to building safety or fire codes. In 2018, an 18-year-old international student that died in a Scarborough (inner Toronto suburb) rooming house fire received ample media attention and once again brought the conversation regarding the legalization of rooming houses to the forefront of municipal debates (Aguilar, 2018). While attempts to legalize rooming houses in parts the city has failed, supporters argue that as-of-right zoning can minimize the bureaucratic hurdles and help ensure that illegal rooming houses are brought up to standard. In an earlier account, Freeman (2014) documented an illegal rooming house landlord that had converted a single-family house into a private market rooming house with 18 rooms and eight bathrooms (Freeman, 2014). Traditionally, illegal rooming houses were viewed as a housing issue that was confined to downtown Toronto; however, recent research contests this claim by documenting the evidence and spread of rooming houses in Toronto's suburban communities as well (Freeman, 2014).

Secondary suites have been permitted in the City of Toronto since 2000, but was considered an informal form of housing prior to zoning by-law amendments.

Secondary suites are defined as

"self-contained living accommodation for an additional person or persons living together as a separate single housekeeping unit, in which both food preparation and sanitary facilities are provided for the exclusive use of the occupants of the suite, located in and subordinate to a dwelling unit." (City of Toronto, 2019b)

The most recent zoning regulations requires that the entire building must have been constructed more than 5 years prior to the introduction of a secondary suite. 
A single secondary suite is permitted in a detached house, a semi-detached house, and a townhouse if it is in a residential zone. Secondary suites in Toronto usually take place in the form of basement apartments, or they may be located within a primary dwelling on a property or within a separate built structure (e.g. above laneway garages). Secondary suites are sometimes referred to as second units, basement apartments, accessory apartments, granny flats, in-law apartments or nanny suites. Laneway housing (or laneway suites) is another example of unconventional housing morphology that is present in the Toronto area and in the Canadian context. Although this form of housing was previously rejected by municipal staff as a form of good planning, the city passed an official zoning by-law amendment in 2018 to permit laneway suites. A laneway suite is a self-contained residential unit located on the same property lot as a detached house, semi-detached house or townhouse, and is generally located in the rear yard of the principal dwelling fronting onto a residential laneway (Race et al., 2017). When regulated, laneway and secondary suites present opportunities to add gentle density to residential communities without significantly altering neighbourhood characteristics, while also increasing rental unit supply, accommodate aging in place, as well as provide income support for homeowners. 


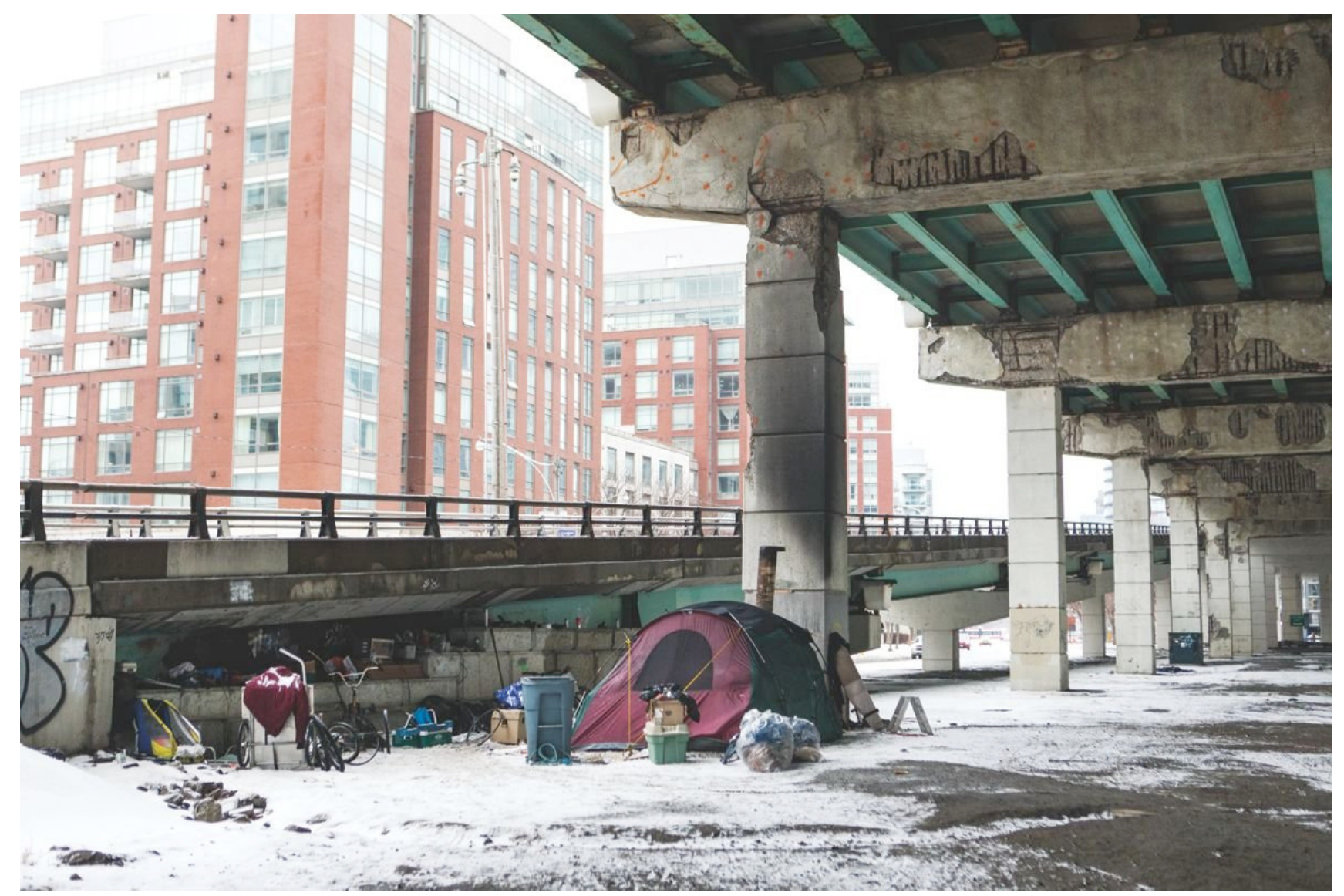

Image 2. Photo of the outdoor encampment of a homeless individual in Toronto, (Biesterfeld \& Engelking, 2019).

\section{Public Housing Provisions}

A more visible morphology of precarious housing in Toronto are the outdoor encampments of homeless individuals on publicly-owned land. In recent years, a number of advocacy group and municipal staff have weighed in on Toronto's homelessness crisis (Progress Toronto, 2019). City Councillor Kristyn Wong-Tam have publicly expressed that "[Toronto is] experiencing a [housing affordability] crisis and homelessness crisis that requires immediate emergency attention. We have people living under The Gardiner [Expressway], living in the ravines, living in the parks". (Knope, 2019) The City of Toronto has mainly responded to this issue with emergency shelter systems, however most of the existing shelter systems are already at 
or overcapacity. In addition, homeless individuals who have built makeshift homes on publicly-owned land have been served eviction notices from the city with no other alternatives (D'Amore, 2019).

Originally, government-funded housing programs were intended to serve returning World War II veterans (Housing Services Corporation, n.d.). Between the 1970s and 1990s, the City adopted a mixed-income community model, focusing mainly on rent-geared to income housing, and in 1978, the deinstitutionalization of mental health patients created a new wave of demands for public housing in the City. From 1998, the provincial government downloaded public housing provisions to local governments, including all capital and operating expenses. Then in 2000, the Social Housing Reform Act mandated that housing priority be given to victims of abuse across the Province of Ontario. Prior to the 1998 amalgamation of the City of Toronto, there were three municipally owned affordable housing agencies, operated by various levels of government. Toronto Community Housing Corporation ( $\mathrm{TCHC}$ ) was formed in 2002, following a merging of Metropolitan Toronto Housing Corporation, Toronto Housing Company Ltd., and the City of Toronto Non-Profit Housing Corporation (also known as Cityhome). TCHC is a non-profit public agency wholly owned by the City of Toronto, as mandated by the Province of Ontario's Housing Services Act. Since the downloading of public housing provisions to the local level, cities have struggled to adequately meet public housing demands with their annual operating budgets.

The City of Toronto has mobilized a number of new housing initiatives and incentive programs in recent years, such as the Open Door Affordable Housing Program, aimed to accelerate affordable rental housing construction through City funding, fast-tracking planning approvals, and activation of surplus public lands which have been successful in exceeding previous levels of affordable rental approvals 
(City of Toronto, 2019a). Other incentives include increases to Development Charges funding for new affordable rental housing developments, funding for housing priority areas (especially around transit nodes), and the implementation of inclusionary zoning to create affordable rental and home ownership.

\section{Social, Economic, Political Forces}

Some of the social, economic, and political conditions that contribute to informal housing in Toronto include: the high demand for affordable rental housing, a lack of affordable rental units being built, increased population growth driven by newcomers, low vacancy rates, and a lack of strong political will to end the housing crisis (Zine, 2002). Individuals belonging to certain age, gender, language, mental health, race, religion, and sexuality also face additional barriers to accessing and maintaining adequate and affordable housing.

Meanwhile, a troubling trend has emerged in Toronto over the past 30 years. Rising poverty rates and growing income polarization has led the city to be more divided than ever before along income and socio- economic lines. Many neighbourhoods have seen significant amounts of new housing built, but 95 per cent of new developments cater towards the ownership market (City of Toronto, 2009). The City recognizes unaffordability as the key driver of core housing need (City of Toronto, 2019a).

Toronto also has some of the longest social housing waitlists in the country, with many families waiting 10-12 years depending on needs and unit size. In addition, the cost of capital repairs and renewal projects fall entirely on the City and expiring social housing operating agreements means further potential loss of affordable housing stock. On a citywide level, wages are simply not rising fast enough to keep with housing costs. 
Since the 1998 amalgamation, the city has had divergent zoning and licensing bylaws in the former boundaries of suburban municipalities such as Scarborough and North York, particularly in regards to housing regulations relating to rooming houses. While the city continues to experiment with new forms of infill housing to provide additional density, such as laneway suites, gaining political support from municipal decision makers is vital for ensuring implementation. It is important to note that while laneway housing may be a tool to promote densification across the city, this tool alone cannot resolve the housing affordability issue in Toronto; rather, it should be viewed as one of the possible solutions.

\section{Current Challenges}

The current landscape of housing in Toronto is marked by unaffordability, low vacancy rates and rental housing stock, aging social housing infrastructure, and shelters that are filled to capacity. These socio-economic circumstances, as well as changing immigrant settlement patterns from the downtown to suburban communities have resulted in evidence of informal housing arrangements across the city, especially in communities with higher newcomer populations, university students, as well as high income polarization. A labyrinth of zoning bylaws and competing community policies across the city have complicated the process for legalizing some forms of informal housing that could provide benefits on a citywide scale. 


\section{DISCUSSION}

Looking at the cities as a whole, Hong Kong is characterized by a dynamic and rapidly growing economy, extreme density due a lack of available land suitable for development, socio-economic stratification, and deteriorating living conditions and environments. In New York City, much of the informal housing takes the form of unregulated accessory dwelling units and informal densities. While rising property prices has increased the demand for affordable housing options in New York City's five boroughs, non-compliance, non-enforcement, and deregulated economic activity has contributed to the sustained proliferation of informal dwellings. In Toronto, population growth has caused demand to outpace the supply of affordable housing, but there is a lack of strong political will to solve the housing crisis. A widening gap between income groups, long social housing wait times, and the homelessness crisis has further contributed to the deterioration of the city's shelter system.

The findings of this paper support prior research documenting the continuing socio-spatial stratification within global cities, and the need for to support vulnerable populations - particularly in terms of short- and long-term housing. The presence and persistence of informal housing may therefore be viewed as an indicator for planning policies that are not responding well to neighbourhood change. As such, cities must continue to adapt their policies with innovative practices and policy interventions that respond to existing demands. The following precedent projects can serve as international best practices for Hong Kong, New York City, and Toronto to follow.

\section{Precedent Project in the Global South: Western Cape, South Africa}

As of 2016, an estimated 1.4 million households were housed in 2, 600 informal settlements across South Africa (Western Cape Government, 2016). Previous stateled programs to upgrade informal settlements have failed to create meaningful 
improvements to residents' quality-of-life as efforts were directed towards isolated projects on peripheral sites. Previous programs also involved the mass relocation of communities with little consideration for the social aspect of community living within informal settlements (Western Cape Government, 2016). In addition, the lack of longterm vision made it impossible to keep up with high rates of urbanization, population growth, financial constraints, and rising development costs. In 2016, the West Cape Government published a Informal Settlement Strategic Framework (ISSF) with an associated Implementation Plan and Monitoring and Evaluation Framework to guide developments through 2030. The purpose of the initiative is to ensure that informal settlement upgrading is systematically prioritized, and takes a progressive and participatory approach. The strategy focuses on community mobilization, and the codesign of spaces, housing, and services.
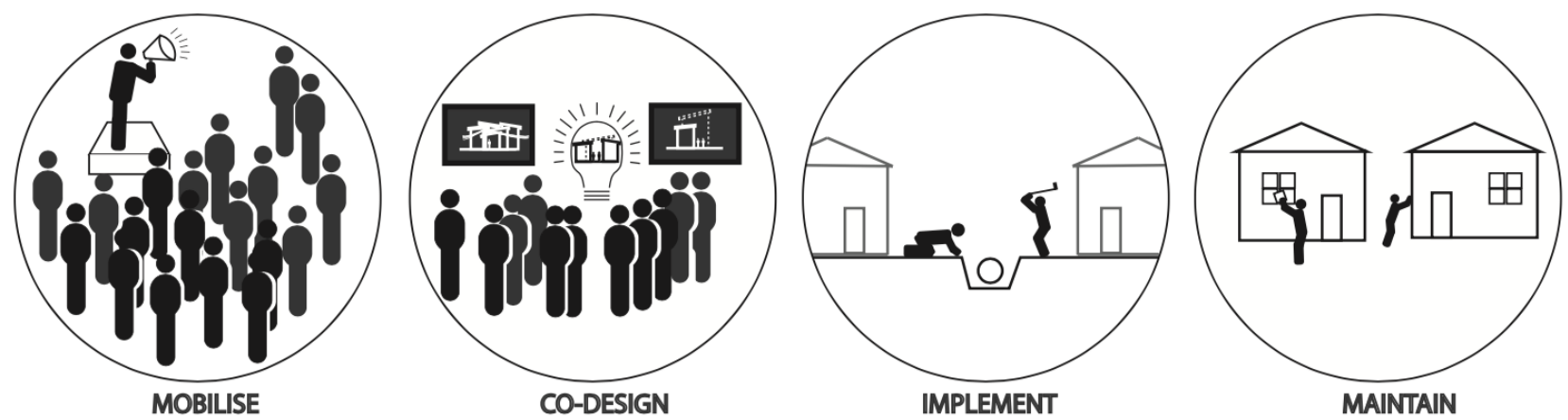

Figure 2. Community-based planning elements (Western Cape Government, 2016).

The Informal Settlement Strategic Framework outlines a variety of practical options that municipal decision makers can adopt to upgrade informal settlements into liveable, integrated, vibrant and resilient neighbourhoods. This framework has already inspired a number of projects in South Africa; the Upgrading for Growth Initiative in Ekurhuleni is one example. The initiative is a joint effort between the Ekurhuleni Metropolitan Municipality, Cities Alliance, and the World Bank. The municipality struggled with vast social and economic disparities, with 65 percent of its population 
living in informal settlements. Since then, the city has adopted a slum upgrading approach that is centered around sustainable economic development and empowering residents.

\section{Lessons Learned from South Africa:}

- Informal settlement upgrading should take a collaborative approach through community-based planning principles;

- Informal settlement upgrading should begin with asset identification and strategic prioritization of resources;

- Local economic development can help integrate low-income populations into larger markets, providing more opportunities for growth; and

- Upgrading informal settlements is more than a technical intervention to improve housing conditions, it should involve a comprehensive methodology that can improve the social, cultural, and economic quality-of-life for inhabitants in a sustainable way.

\section{Precedent Project in the Global North: Vienna, Austria}

A hundred years ago, housing unaffordability was a major issue for Vienna's working-class residents. Many workers lived in overcrowded flats ranging from 10 to 300 square feet, and shared beds with multiple other individuals to help cover the cost of rent (Condon, 2018). Public policy at the time favoured landlords, and renters had little to no rental protection. All rental terms were set at the mercy of landlords, and the city experienced a severe homelessness crisis. 


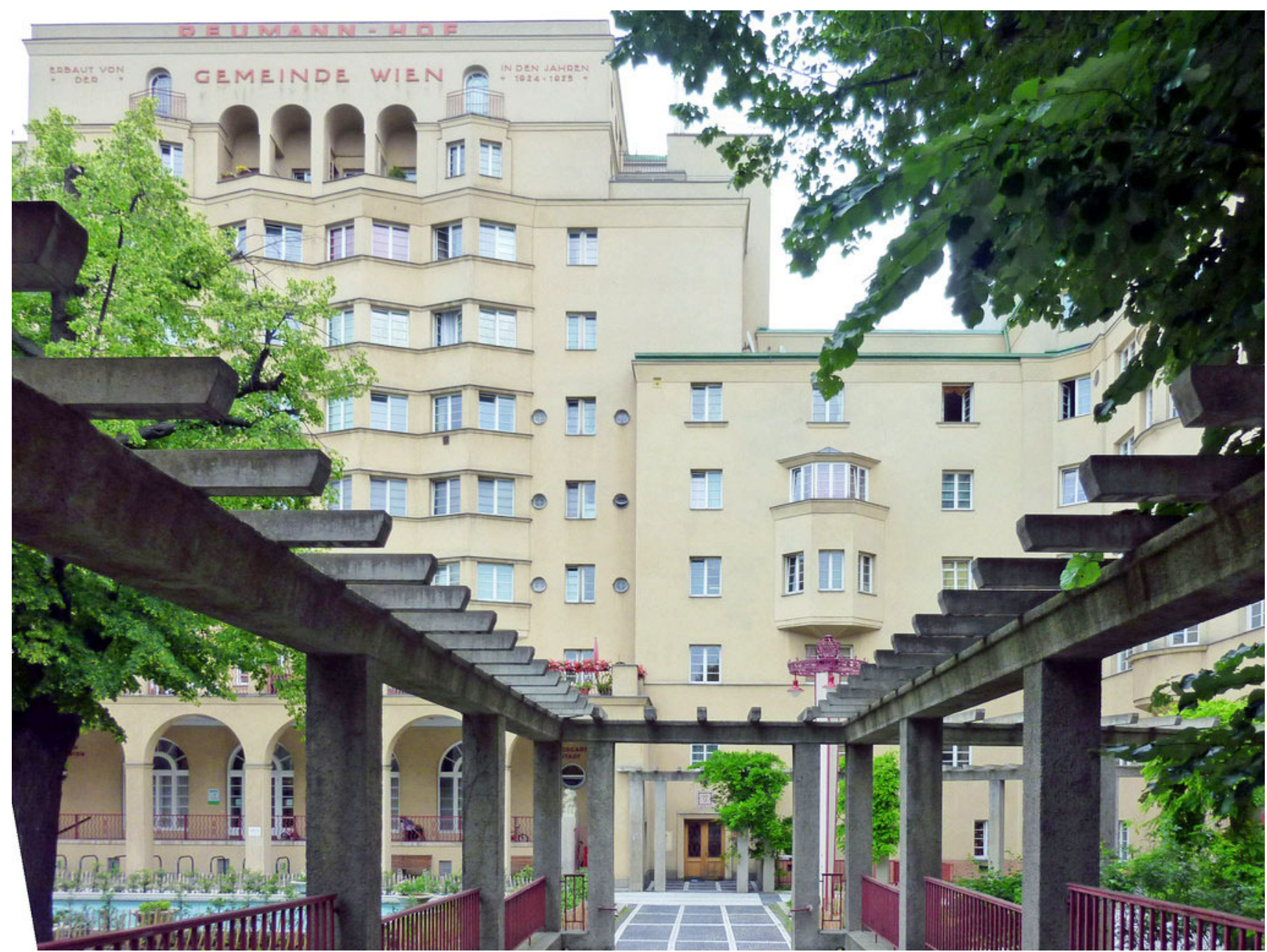

Figure 3. Reumann-Hof social housing complex, built in 1923 (Fitzpatrick, 2017).

Fast forward to today, Vienna frequently tops the list for being one of the most affordable cities to live in the world (Fitzpatrick, 2017). More than two-thirds of the city's population resides in city-built, subsidized or managed housing (Condon, 2018). On average, residents spend 20 percent of their income on rent, compared to the significantly higher UK average which is 50 percent (Paasikivi, n.d.). 


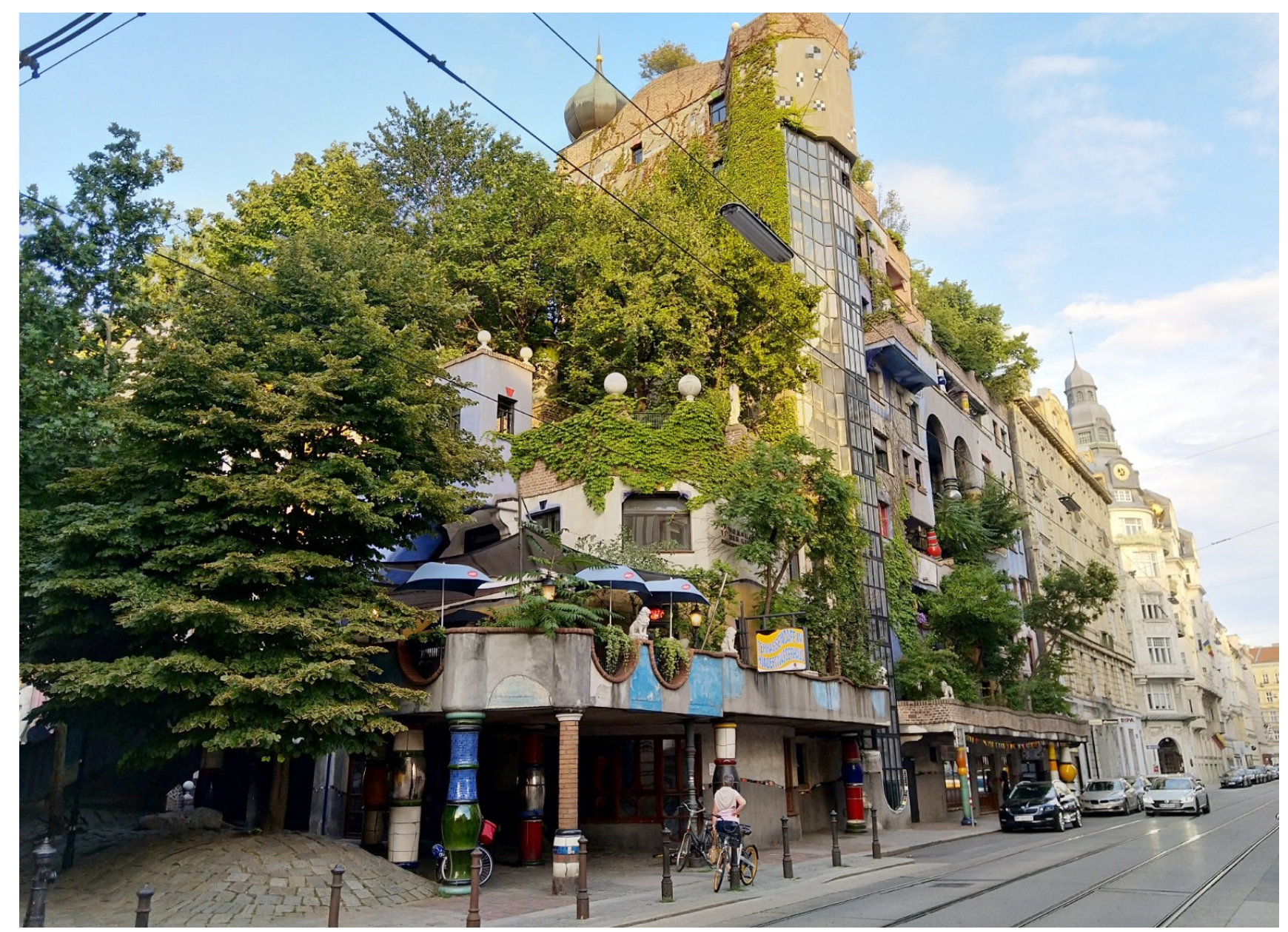

Image 4. Hundertwasser Social Housing Project, Vienna.

\section{Lessons Learned from Vienna:}

- Employing strict rent control may lower the supply affordable rentals in the shortterm, but in Vienna, this policy intervention eventually led to lowered average rental rates across the city;

- Municipal governments should seek to acquire more land and protect existing publicly-owned land to serve core housing needs;

- The city engaged in cross-sectoral collaboration to ensure that the new public housing projects met design and planning excellence;

- Public housing was created with the intention to serve a range of social groups;

- Increased budget allocations towards buying land and financing public housing; and 
- Induced friendly competition between non-profit development corporations for citysponsored projects. 


\section{CONCLUSION}

There is no universal way to respond to informal housing. The three global cities examined in this paper provided a glimpse into this international phenomenon, demonstrating that the existence of informal housing arrangements transcend cultures and borders. While each city faces a distinct set of socio-economic and political drivers, informal housing plays an undeniable role in providing affordable housing to different cohorts of a population.

Urban planners should recognize that informal housing can take many forms, some of which have shown to be more efficient at meeting community needs than efforts derived from formal planning. However, it should also be recognized that an appropriate response to improving informal housing means thinking beyond bureaucratic or technical matters, and applying sustainable development principles.

The term informal housing have traditionally held a negative connotation in both academic research and social perceptions. Part of this requires a shift in attitude towards how informal housing is built and viewed. To understand a community's needs and desires is to understand its history, culture, individuals and relationships. Informal housing should not be viewed as an unplannable urban phenomenon to be entirely replaced, rather it should be studied on a case by case basis. They should be built in a way that is rooted in community empowerment, sustainable, and led by long-term vision. 


\section{REFERENCE LIST}

Abbott, J. (2002). A method-based planning framework for informal settlement upgrading. Habitat International, 26(3), 317-333.

Aguilar, B. (2018). 'It is disgusting,' says councillor of city's failure to regulate rooming houses / The Star. Retrieved from https://www.thestar.com/news/gta/2018/06/01/it-is-disgusting-says-councillorof-citys-failure-to-regulate-rooming-houses.html

Al, S. (2014). Villages in the city: A guide to south china's informal settlements. Hong Kong University Press.

Biesterfeld, P. \& Engelking, S. (2019). Mayor John Tory's response to Toronto's homelessness crisis has been a disaster. Retrieved from https://nowtoronto.com/news/john-tory-homelessness-crisis/

Chen, et. al. (2018). Socio-spatial polarization and the (re-)distribution of deprived groups in world cities: A case study of Hong Kong. Urban Geography, 1-19.

Chui, T., Flanders, J., \& Anderson, T. (2018). Immigration and Ethnocultural Diversity in Canada. Retrieved from http://www12.statcan.gc.ca/nhs-enm/2011/as-sa/99-010-x/99-010-x2011001eng.cfm

Citizens Housing and Planning Council. (2003). New York's Underground Housing. The Urban Prospect, 9(2), 1-4

City of New York. (2018). Selected Findings of the 2017 New York City Housing and Vacancy Survey. Retrieved from https://www1.nyc.gov/assets/hpd/downloads/pdf/about/2017-hvs-initialfindings.pdf

City of Toronto. (2009). Housing Opportunities Toronto An Affordable Housing Action Plan 20102020. Retrieved from https://www.toronto.ca/community-people/community-partners/affordablehousing-partners/housing-opportunities-toronto-affordable-housing-action-plan-2010-2020/

City of Toronto. (2017). 2016 Census: Population and Dwelling Counts. Retrieved from https://www.toronto.ca/wp-content/uploads/2017/10/96b9-2016-Census-BackgrounderPopulation-Dwellings.pdf

City of Toronto. (2018). Multi-tenant Houses (Rooming Houses). Retrieved from https://www.toronto.ca/city-government/public-notices-bylaws/bylaw-enforcement/multi-tenanthouses-rooming-houses/.

City of Toronto. (2019a). Affordable Housing - Housing Affordability, Availability, and Repair. Council Issue Notes. Retrieved from https://www.toronto.ca/city-government/council/2018-council-issuenotes/torontos-housing/housing-affordability-availability-repair/

City of Toronto. (2019b). Overview. Secondary Suites. Retrieved from https://www.toronto.ca/citygovernment/planning-development/planning-studies-initiatives/secondary-suites/overviewsecondary-suites/ 
Condon, P. (2018). How Vienna Cracked the Case of Housing Affordability. Retrieved from https://thetyee.ca/Solutions/2018/06/06/Vienna-Housing-Affordability-Case-Cracked/? fbclid=IwAR05EU1SA86cQhikoeUF8KQGW_1Fhy9rK2hhxO0JihmBf8Qc3951_st2h3Y

D'Amore, R. (2019). City giving homeless living in tent cities 2 weeks to vacate structures. Retrieved from https://toronto.ctvnews. ca/city-giving-homeless-living-in-tent-cities-2-weeks-to-vacatestructures-1. 4254610

Department of City Planning New York City. (2019). "About DCP". Retreived from https://www1.nyc.gov/site/planning/about/department.page

DeWolf, C. (2017). Borrowed Spaces: Life Between the Cracks of Modern Hong Kong. Penguin Group Australia.

Durst, N. J., \& Wegmann, J. (2017). Informal housing in the United States. International Journal of Urban and Regional Research, 41(2), 282-297.

Fitzpatrick, M. (2017). What could Vienna's low-cost housing policy teach the UK? Retrieved from https.//www.theguardian.com/society/2017/dec/12/vienna-housing-policy-uk-rent-controls

Freeman, L. (2014). Toronto's Suburban Rooming Houses: Just a Spin on a Downtown "Problem"? Wellesley Institute.

Government of Hong Kong. (2017). Hong Kong Poverty Situation Report 2017. Retrieved from https.//wWw.statistics.gov.hk/pub/B9XX0005E2017AN17E0100.pdf

Government of Hong Kong. (2018) Town Planning. Retrieved from https://www.gov.hk/en/about/abouthk/factsheets/docs/town_planning.pdf

Government of Hong Kong Census and Statistics Department. (2019). Hong Kong Statistics. Retrieved from https://www.censtatd.gov.hk/hkstat/sub/so20.jsp

Government of Hong Kong Planning Department. (2007) Hong Kong: 2030 Planning Vision and Strategy. pp. 34 Retrieved from

https.//www.pland.gov.hk/pland_en/p_study/comp_s/hk2030/eng/finalreport/pdf/E_4.pdf

Hong Kong Department of Lands (2016). Squatter Control policy on surveyed squatter structures. Retrieved from http://www.landsd.gov.hk/en/squatter_control/sqctrl. htm.

Housing Services Corporation. (n.d.). Social and Affordable Housing Primer. Retrieved from https://share.hscorp.ca/affordable-housing/?upf=dl\&id=4296

Knope, J. (2019). Declare Toronto homelessness a state of emergency, advocate group says. CBC. Retrieved from https://wWw.cbc.ca/news/canada/toronto/declare-toronto-homelessness-a-state-ofemergency-advocate-group-says-1.4987854

Kutty, N. K. (2005). Evaluation of the Federal Housing Choice Voucher Program under a Welfare Economics Framework. Retrieved from https.//papers. ssin.com/sol3/papers.cfm? abstract_id=999678

Lai, L. W. C. (2015). Squatting by the privileged? A Hong Kong study on the innovations and ambiguity of property rights of irregular development. Habitat International, 50, 317-325. doi:10.1016/j.habitatint.2015.09.003 
Lam, B. (2017). Boxed in: life inside the 'coffin cubicles' of Hong Kong - in pictures. Retrieved from https://www.theguardian.com/cities/gallery/2017/jun/07/boxed-life-inside-hong-kong-coffincubicles-cage-homes-in-pictures

Massey, D. S. (2003). Patterns and processes of international migration in the 21st century. In Conference on African Migration in Comparative Perspective, Johannesburg, South Africa(Vol. 4, No 7, pp. 1-41).

Mukhija, V., \& Loukaitou-Sideris, A. (2014). The informal American city: Beyond taco trucks and day labor. MITPress.

New York City Department of Finance. (2016). "Department of Finance Publishes Fiscal Year 2017 Tentative Assessment Roll". Retrieved from

https://www1.nyc.gov/assets/finance/downloads/pdf/press_release/fy2017_tentative_assessment _roll.pdf

New York State Homes and Community Renewal. (2019). "Mitchell-Lama Housing Program". Retrieved from http://www.nyshcr.org/Programs/Mitchell-Lama/

By Paasikivi - Own work, CC BY-SA 4.0, https://commons. wikimedia.org/w/index.php? curid $=71031019$

Paasikivi. (2018). Hundertwasserhaus Wienissä. Retrieved from https.//commons.wikimedia.org/wiki/File:Hundertwasserhaus_(Vienna,_Austria)_(Wien,_Itävalta)_20 18_08.jpg\#/media/File:Hundertwasserhaus_(Vienna,_Austria)_(Wien,_Itävalta)_2018_08.jpg

Progress Toronto. (2019). Declare Homelessness and Housing a State of Emergency in Toronto. Retreived from https://www.progresstoronto.ca/take-action-to-declare-homelessness-a-crisis

Race, C., et al. (2017) Laneway Suites A New Housing Typology for Toronto. Lanescape. Evergreen.

Roy, A., \& AlSayyad, N. (Eds.). (2004). Urban informality: Transnational perspectives from the middle East, latin America, and south Asia. Lexington Books.

Roy, A. (2005). Urban informality: toward an epistemology of planning. Journal of the american planning association, 71(2), 147-158.

Smart, A. (1989). Forgotten obstacles, neglected forces: explaining the origins of Hong Kong public housing. Environment and Planning D: Society and Space, 7(2), 179-196

Smart, A. (2003). Impeded self-help: toleration and the proscription of housing consolidation in Hong Kong's squatter areas. Habitat International, 27(2), 205-225.

Soyinka, O., \& Siu, K. W. M. (2017). Investigating informal settlement and infrastructure adequacy for future resilient urban center in Hong Kong, SAR. Procedia Engineering, 198, 84-98.

Town of Richmond Hill. (2019). Basement Apartments of Second Units. Retrieved from https.//www.richmondhill.ca/en/find-or-learn-about/Basement-Apartments-or-Second-Units. aspx

The New York Times. (2018). "New York City's Population Hits a Record of 8.6 Million". Retrieved from https.//www.nytimes.com/2018/03/22/nyregion/new-york-city-population.html

UN Habitat. (2012). Informal Urbanism - About. UN Habitat. http://uni.unhabitat.org/informalurbanism-about/ 
United States Federal Government. (2019). "Housing Choice Voucher Program (Section 8)". Retrieved from https://www.benefits.gov/benefit/710

Waldrep, M. (2014). Informal housing in New York City: a spatial history of squats, lofts, and illegal conversions (Doctoral dissertation, Massachusetts Institute of Technology).

Wang, Y., Wang, Y., \& WU, J. (2009). Urbanization and Informal Development in China: Urban Villages in Shenzhen. International Journal Of Urban And Regional Research, 33(4), 957-973.

Western Cape Government. (2016). Towards Incremental Informal Settlement Upgrading: Supporting Municipalities in Identifying Contextually Appropriate Solutions. Retrieved from https://www.salzburgglobal.org/fileadmin/user_upload/Documents/20102019/2018/Session_595/Western_Cape_ISSP_Design__Tenure_Options_2016.pdf

Zine, J. (2002). Living on the Ragged Edges: Absolute and hidden homelessness among Latin Americans and Muslims in West Central Toronto. Equinox Research and Consulting Services. Retrieved from http://www. urbancentre.utoronto.ca/pdfs/elibrary/Zine_Ragged-Edges-IHNPSumm.pdf 